\title{
On the Kinetic Behavior of Recycling Precious Metals (Au, Ag, Pt, and Pd) Through Copper Smelting Process
}

\author{
Xingbang Wan $^{1}$ (D) $\cdot$ Lotta Kleemola $^{1}$ (D) Lassi Klemettinen $^{1}$ (D) Hugh O'Brien $^{2}$ (D) $\cdot$ Pekka Taskinen $^{1}$ (D) \\ Ari Jokilaakso ${ }^{1}$ (D)
}

Received: 16 February 2021 / Accepted: 2 June 2021 / Published online: 9 June 2021

(c) The Author(s) 2021

\begin{abstract}
The recycling and recovery of precious metals from secondary materials, such as waste-printed circuit boards, are an important area of circular economy research due to the limited existing resources and increasing amount of e-waste produced by the rapid development of technology. In this study, the kinetic behavior of precious metals $\mathrm{Au}, \mathrm{Ag}, \mathrm{Pt}$, and Pd between copper matte and iron-silicate slag was investigated at a typical flash smelting temperature of $1300^{\circ} \mathrm{C}$ in both air and argon atmospheres. SEM-EDS, EPMA, and LA-ICP-MS-advanced analysis methods were used for sample characterization. The results indicate that precious metals favor the matte phase over slag, and the deportment to matte occurred swiftly within a short time after the system had reached the experimental temperature. With increasing contact times, the precious metals were distributed increasingly into the sulfide matte. The distribution coefficients, based on experimentally measured element concentrations, followed the order of palladium $>$ platinum $>$ gold $>$ silver in both air and argon, and the matte acted as an efficient collector of these precious metals. The obtained results can be applied to industrial copper matte smelting processes, and they also help in upgrading CFD models to simulate the flash smelting process more precisely.
\end{abstract}

The contributing editor for this article was Yongxiang Yang.

Ari Jokilaakso

ari.jokilaakso@aalto.fi

Xingbang Wan

xingbang.wan@aalto.fi

Lotta Kleemola

lotta.kleemola@aalto.fi

Lassi Klemettinen

lassi.klemettinen@aalto.fi

Hugh O'Brien

hugh.obrien@gtk.fi

Pekka Taskinen

pekka.taskinen@aalto.fi

1 Department of Chemical and Metallurgical Engineering,

School of Chemical Engineering, Aalto University, P.O.

Box 16100, 00076 Aalto, Finland

2 Geological Survey of Finland, Vuorimiehentie 2,

02150 Espoo, Finland 


\section{Graphical Abstract}

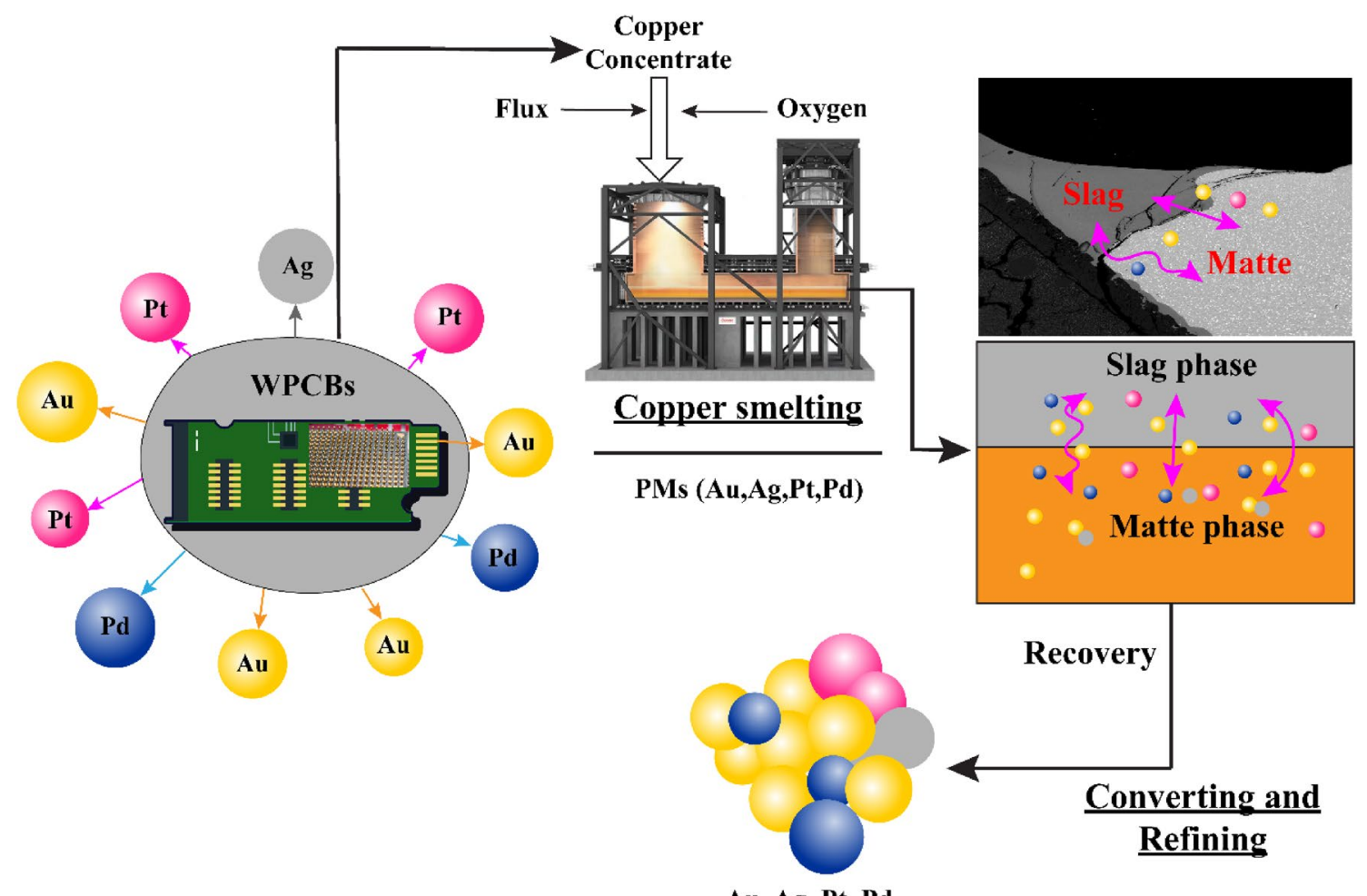

Keywords WPCB $\cdot$ Recycling $\cdot$ Flash smelting $\cdot$ Iron-silicate slag $\cdot$ Distribution coefficients

\section{Introduction}

Due to technological advances and the improvement of economic and social conditions around the globe, the number of electronic devices in total and per capita is increasing. Meanwhile, the lifecycle of devices has become shorter as a result of rapid technology updates and increasing disposable income [1]. The United Nations University has estimated that, for example, in 2016, the global generation of WEEE (waste electrical and electronic equipment) was 44.7 million tons [2] and in 2018, 49.8 million tons [3], and it is expected to reach 52.2 million tons by 2021 [4]. WEEE consists of a wide range of materials, some of which have very high economic value. Due to the huge amounts produced every year, WEEE is considered as a valuable urban resource. Various methods, such as physical separation, electrostatic separation, pyrometallurgical, and hydrometallurgical processes have been investigated with the focus of recycling the valuable metals from these secondary resources $[5,6]$.

Reprocessing WEEE to recover the valuable metals is not a simple task. WEEE is a heterogeneous mixture of metallic and non-metallic fractions, where the components containing valuable metals are strongly bonded to other components that may have little or no value [7, 8]. Furthermore, common electronic devices may include lead, mercury, and arsenic, which are hazardous elements. Proper management of e-waste is, therefore, a must, as it can pollute ground water, acidify the soil, generate toxic fumes and gases in burning, accumulate in municipal disposal areas, and release carcinogenic substances [9].

Waste-printed circuit boards (WPCBs) are an important part of WEEE: they account for 2-3\% of its total mass [4, 10]. WPCBs consist mostly of nonconductive insulator materials and several metals, such as copper and precious metals (PMs). The concentrations of PMs, specifically gold, silver, platinum, and palladium, in WPCBs can be considerably higher than in their primary sources [11]. Moreover, as primary precious metal resources are steadily depleting, the demand for these metals is growing in many sectors. Therefore, recycling of precious metals from WPCBs is of significant interest. The value of precious metals comprises $80 \%$ of the value of scrap electronic devices, despite their small quantities [12]. For these reasons, manufacturers, environmental agencies, and governments around the globe are attempting to find systematic and environmentally sustainable ways of recycling precious metals from WPCBs. 
Pyrometallurgical processes are capable of dealing with complex e-waste streams [13-16]. WPCBs, in addition to their high precious metal content, also contain more than $20 \%$ copper [17]. Considering the economic and technical aspects, copper smelting is one of the predominant routes for WPCB and e-waste recycling [18]. Copper flash smelting is a mature technology that has been studied and employed by industry for decades [19-21], and the combustion reactions of chalcopyrite and other sulfides in it have also been widely investigated [22-25]. WPCBs can be processed along with the primary feed of copper concentrates. However, the elemental composition of WPCBs and other e-waste is often such that it can affect the processing conditions, for instance by changing the liquidus temperature or viscosity of the slag or by making the slag more corrosive towards refractories. Another issue related to WPCB smelting is that the mix of elements in WPCB does not match that in common primary mineral concentrates, for which the smelting technology has been optimized over many years and for which a large database of information has accumulated [7, 26-28].

To obtain the optimal process parameters for WPCB smelting and precious metals recovery, the thermodynamics and kinetic behavior of the valuable elements and their reaction mechanisms must be known. Equilibrium research regarding the precious metal distribution between matte and different slags has been intensively carried out during the past few decades. The investigated slag systems include, for example, $\mathrm{FeO}_{x}-\mathrm{CaO}$ [29], $\mathrm{FeO}_{x}-\mathrm{SiO}_{2}$ [30, 31], $\mathrm{FeO}_{x}-\mathrm{SiO}_{2}-\mathrm{MgO}$ [32], and $\mathrm{SiO}_{2}-\mathrm{CaO}-\mathrm{FeO}_{x}-\mathrm{MgO}$ [33]. The distribution characteristics have also been studied as a function of matte grade with various sulfur and oxygen potentials [34-36]. However, studies on the kinetic behavior of precious metals in the matte-slag system are lacking [37], and more research is urgently needed to optimize the methods to recover precious metals from WPCBs through the copper smelting process.

The time dependency of precious metal ( $\mathrm{Au}, \mathrm{Ag}, \mathrm{Pt}$, and $\mathrm{Pd}$ ) distribution was experimentally investigated in laboratory-scale copper matte smelting conditions. The results contribute to deeper understanding of PM distribution behavior during the settling process in the flash smelting furnace (FSF) and provide guidance in finding better strategies and methods for recovering the precious and platinum group metals from e-waste via pyrometallurgical routes.

\section{Experimental}

\section{Materials}

The raw materials used in this study were industrial chalcopyrite copper concentrate, synthetic iron oxide-silica slag, and $\mathrm{PM}$ (Ag, Au, Pt, Pd) powders. The concentrate was provided by Boliden Harjavalta, Finland. Its chemical composition was analyzed by X-ray fluorescence (XRF) spectrometry (Malvern Panalytical B.V., Almelo, The Netherlands) and is shown in Table 1.

The iron oxide-silica slag was prepared by mixing $65 \mathrm{wt} \%$ of hematite powder (Alfa Aesar, 99.99\% purity) with $35 \mathrm{wt} \%$ of silica powder (Umicore, $99.99 \%$ purity). The preparation of the slag has been described in detail in a previous study [38]. Instead of real WPCB, pure Ag, Au, Pt, and Pd powders (Alfa Aesar, $\geq 99.9 \%$ purity) were used as sources of precious metals in the experiments.

\section{Apparatus and Procedures}

The experimental apparatus used in this study is shown in Fig. 1 and has been described in detail earlier [24]. The silica crucible, filled with sample material, was raised into the hot zone (temperature $1300{ }^{\circ} \mathrm{C}$ ) with a Pt-hanging wire. After a preset time, the reactions were stopped by dropping the sample into a quenching vessel filled with ice water. For the experiments in an argon atmosphere, the work tube was sealed from the bottom, and a flow of 400-500 mL/min argon (AgA Linde, 99.999\% purity) was used.

A slag to concentrate ratio of 1.116 was chosen in accordance with industrial operation practice [24]; this corresponds to a $\mathrm{SiO}_{2} / \mathrm{Fe}$ flux ratio of 0.53 . Usually, the PM concentrations in real WPCBs are relatively low (varying from 80 to $3300 \mathrm{ppm}$ ) [39]. In this study, the amount of each metal (gold, silver, palladium, and platinum) was measured to be $2.5 \mathrm{wt} \%$ of the amount of concentrate (Table 2) considering the detection limitations of EPMA and LA-ICP-MS analyses [30, 34]. All the powders were ground together in a mortar to obtain a homogenous slag-concentrate-PM mixture. The mixture was then inserted into cone-shaped silica crucibles (Finnish Special Glass, Finland) with a mixture sample weight of $0.5236 \mathrm{~g}$ for each experiment, measured by an analytical balance (AB204, Mettler Toledo, USA).

The contact times were chosen to be 10, 20, 30,60, 150, 300 , and $600 \mathrm{~s}$ in air. For experiments in an argon atmosphere, 5, 10, 20, and 40 min were chosen. Each experiment
Table 1 Chemical composition of the copper concentrate (wt \%)

\begin{tabular}{llllllllll}
\hline $\mathrm{Cu}$ & $\mathrm{Fe}$ & $\mathrm{S}$ & $\mathrm{Zn}$ & $\mathrm{Ca}$ & $\mathrm{Cr}$ & $\mathrm{Pb}$ & $\mathrm{SiO}_{2}$ & $\mathrm{Ag}$ & $\mathrm{Au}$ \\
\hline 29.2 & 27.1 & 34.5 & 4.3 & 0.07 & 0.01 & 0.1 & 2.5 & $205 \mathrm{ppm}$ & $4 \mathrm{ppm}$ \\
\hline
\end{tabular}




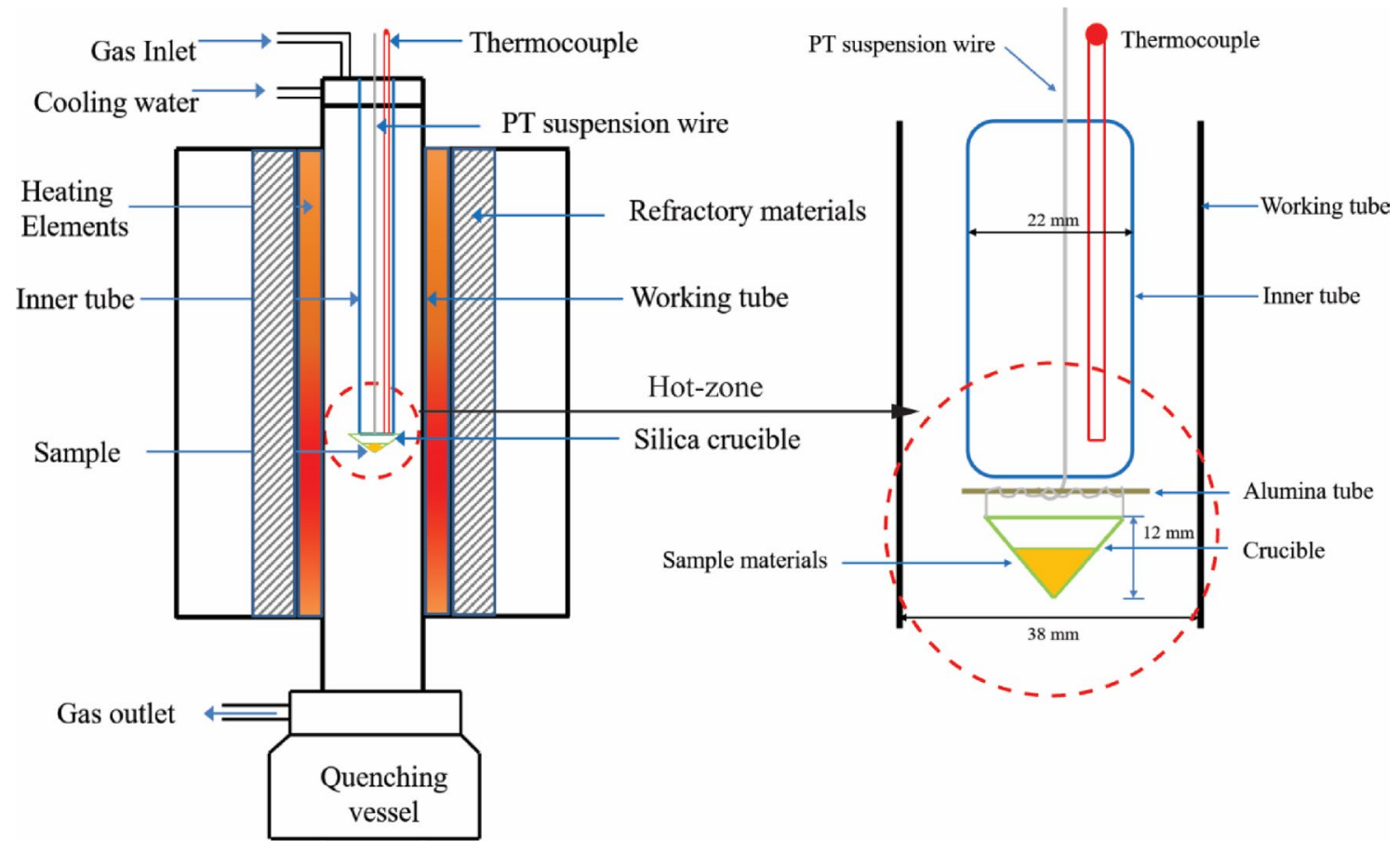

Fig. 1 Schematic of the furnace and geometric details of the hot zone

Table 2 Mass contents of the raw materials in each experiment

\begin{tabular}{llllllll}
\hline Material & Chalcopyrite concentrate $(\mathrm{g})$ & Iron oxide-silica slag $(\mathrm{g})$ & $\mathrm{Au}(\mathrm{g})$ & $\mathrm{Ag}(\mathrm{g})$ & $\mathrm{Pt}(\mathrm{g})$ & $\mathrm{Pd}(\mathrm{g})$ & $\mathrm{Total}$ weight $(\mathrm{g})$ \\
\hline Weight & 0.2363 & 0.2637 & 0.0059 & 0.0059 & 0.0059 & 0.0059 & 0.5236 \\
\hline
\end{tabular}

was repeated at least twice, and a sufficient number of phase areas was analyzed in every polished section of the samples in order to ensure the reproducibility and reliability of the results.

\section{Analyses}

The samples were prepared with basic metallographic methods and first analyzed with a Mira 3 scanning electron microscope (SEM, Tescan, Brno, Czech Republic) equipped with an UltraDry silicon drift energy dispersive X-ray spectrometer (EDS, Thermo Fisher Scientific, Waltham, MA, USA) coupled to NSS microanalysis software (Thermo Fisher Scientific, Waltham, MA, USA). Considering the insufficient detection limits of EDS [40, 41] and PM concentration results from a previous equilibrium study, the chemical compositions of the matte phase were investigated by electron probe micro-analysis (EPMA) and the slag phase was analyzed by laser ablation-inductively coupled plasmamass spectrometry (LA-ICP-MS). LA-ICP-MS was essential for the slag phase due to its very low PM concentrations.

The EPMA used in this work for matte phase analysis was a Cameca SX100 equipped with five wavelength dispersive spectrometers (Cameca SAS, Gennevilliers, France). The selected accelerating voltage was $20 \mathrm{kV}$, beam current $60 \mathrm{nA}$, and beam diameter $100 \mu \mathrm{m}$. The analyzed lines and standards (Astimex) used were as follows: $\mathrm{Fe} \mathrm{K} \alpha$ and $\mathrm{O} \mathrm{K} \alpha$ (hematite), $\mathrm{Mg} \mathrm{K} \alpha$ (diopside), $\mathrm{S}$ $\mathrm{K} \alpha$ (pentlandite), $\mathrm{Cu} \mathrm{K} \alpha(\mathrm{Cu}), \mathrm{Zn} \mathrm{K} \alpha$ (sphalerite), $\mathrm{Pb} \mathrm{L} \alpha$ (galena), Pd L $\alpha$ (Pd), Ag L $\alpha$ (Ag), Pt L $\alpha$ (Pt), and Au L $\alpha$ (Au).

The equipment used for slag trace element analysis was a Photon Machines Analyte Excite laser ablation system with a $193 \mathrm{~nm}$ wavelength $4 \mathrm{~ns}$ ArF excimer laser (Teledyne CETAC Technologies, Omaha, USA) coupled to an $\mathrm{Nu}$ AttoM single collector sector field ICP-MS (Nu Instruments Ltd., Wrexham, UK). The laser spot size was selected as $65 \mu \mathrm{m}$ for the air-atmosphere experiments, and $40 \mu \mathrm{m}$ for the argon-atmosphere samples, due to the limited size of slag areas available. The obtained detection limits of EPMA and LA-ICP-MS are shown in Table 3, and more detailed information about the technique adopted in our study can be found in the references [34, 40, 42-44]. 
Table 3 EPMA and LA-ICP-MS detection limits in ppmw (parts per million by weight)

\begin{tabular}{|c|c|c|c|c|c|c|c|c|c|c|c|c|}
\hline Elements & & $\mathrm{O}$ & $\mathrm{Si}$ & $\mathrm{S}$ & $\mathrm{Fe}$ & $\mathrm{Cu}$ & $\mathrm{Zn}$ & $\mathrm{Pd}$ & $\mathrm{Ag}$ & $\mathrm{Pt}$ & $\mathrm{Pb}$ & $\mathrm{Au}$ \\
\hline EPMA (matte) & & 1499 & & 138 & 221 & 338 & 397 & 248 & 448 & 797 & 1274 & 1196 \\
\hline \multirow{2}{*}{ LA-ICP-MS (slag) } & $65 \mu \mathrm{m}$ spot & & 3.8 & & & & 0.3 & 0.03 & 0.005 & 0.002 & 0.002 & 0.001 \\
\hline & $40 \mu \mathrm{m}$ spot & & 8.6 & & & & 0.6 & 0.09 & 0.01 & 0.003 & 0.004 & 0.002 \\
\hline
\end{tabular}

\section{Results and Discussion}

\section{Smelting Process and Sample Microstructures}

In this study, copper concentrate, iron oxide-silica slag, and PMs ( $\mathrm{Au}, \mathrm{Ag}, \mathrm{Pt}$, and $\mathrm{Pd}$ ) were pre-mixed and reacted at a typical copper smelting temperature of $1300{ }^{\circ} \mathrm{C}$ in both air and argon atmospheres. The purpose of the airatmosphere experiments was to simulate the reaction shaft processes of the flash smelting furnace, while the argon atmosphere was used for simulating the reactions between matte and slag in low oxygen partial pressure (typically around $10^{-8}$ to $10^{-7} \mathrm{~atm}$ ) on the slag-metal interface in the settler [45].

The SEM-backscattered electron micrographs of samples after different contact times in air are shown in Fig. 2. The reactions proceeded quickly, as the matte (A) and fayalite $\mathrm{FeO}_{x}-\mathrm{SiO}_{2}$ slag (B) phases already began to form after $10 \mathrm{~s}$, which is consistent with the rapid reaction phenomena occurring in the flash smelting process [46]. The structure of the sample was first extremely heterogeneous and the interfaces between the matte and slag phases were not clear. Unreacted ferric oxide (D) was also detected. After $20 \mathrm{~s}$, the fayalite slag areas had increased in size and started to segregate more clearly from the sulfide matte. The matte was rather randomly distributed, which showed that coalescence and settling had not taken place at this point. After $30 \mathrm{~s}$ of contact time, most of the remaining un-melted silica (C) had reacted and dissolved into the slag, and a clear interface between matte and slag was formed. With increasing contact time, phase coalescence and matte settling progressed further. Some areas were detected in the form of a PMs-Cu-Fe droplet clusters (E), and after $30 \mathrm{~s}$, these droplets were found only in the matte phase. From the micrographs in Fig. 2e-f, platinum metal preferred to form these metallic droplets with copper and iron enclosed within the matte phase, while gold, silver, and palladium dispersed more evenly into the matte phase. However, a few Au-, Ag-, and Pd-containing clusters were also detected in the matte phase. In the sample at $150 \mathrm{~s}$, a larger high-platinum content area was found. At $300 \mathrm{~s}$, a large droplet with a platinum core surrounded by a shell formed of copper, iron, and small amounts of PMs was observed in the sample. However, these larger PM clusters and droplets were avoided in the EPMA analyses, which was used to detect the average concentrations of PMs in the matte.
Figure 3 shows the SEM micrographs of samples after different contact times in an argon atmosphere. As shown in Fig. 3a, the matte (A) and fayalite slag (B) phases had already formed and separated from each other after $5 \mathrm{~min}$. PM-rich clusters (D) were detected with all contact times, and they were randomly distributed in the matte domains. Figure $3 b-d$ illustrates the small change in the structure of the samples with increasing contact time from 10 to $40 \mathrm{~min}$. At 40 min of contact time (Fig. 3d), the PM-rich clusters had coalesced into larger droplets and were specifically found near the slag-matte interfaces. As is to be expected with longer contact times, the PMs have more time to migrate and coalesce to form bigger droplets within the matte.

\section{Behavior of Major Elements in Matte and Slag Phases}

The concentrations of major elements in the matte $(\mathrm{Cu}-\mathrm{Fe}-\mathrm{S})$ and slag $\left(\mathrm{FeO}_{x}-\mathrm{SiO}_{2}\right)$ are shown in Figs. 4 (air atmosphere) and 5 (argon atmosphere) as a function of contact time. In air, the matte grade ( $\mathrm{wt} \% \mathrm{Cu}$ ) increased continuously, seen also as a decrease in its iron concentration. The sulfur concentration remained relatively stable with a minor decreasing trend as a function of increasing contact time. After $300 \mathrm{~s}$, the reaction rate decreased, and the matte grade reached a value of approximately $50 \mathrm{wt} \% \mathrm{Cu}$ at $600 \mathrm{~s}$. In the slag phase shown in Fig. $4 \mathrm{~b}$, the silica concentration kept increasing until $60 \mathrm{~s}$, after which the slag composition remained constant. Corresponding to the microstructures shown in Fig. 2, during the first $60 \mathrm{~s}$, the primary silica crystals reacted and dissolved into the slag, and more silica was also dissolved from the crucible.

In the argon atmosphere, the concentrations of major elements in matte and slag phases remained relatively constant throughout the time series. The matte grade stabilized at a considerably lower level than in air, due to the absence of free oxygen. The slag composition was almost the same as that in air. These results were similar to the results of previous experiments conducted in the same conditions but with different trace elements [40].

\section{Behavior of Precious Metals in Matte and Slag Phases}

The concentrations of the PMs Au, Ag, Pt, and Pd in matte as a function of time are shown in Fig. 6. In air atmosphere 


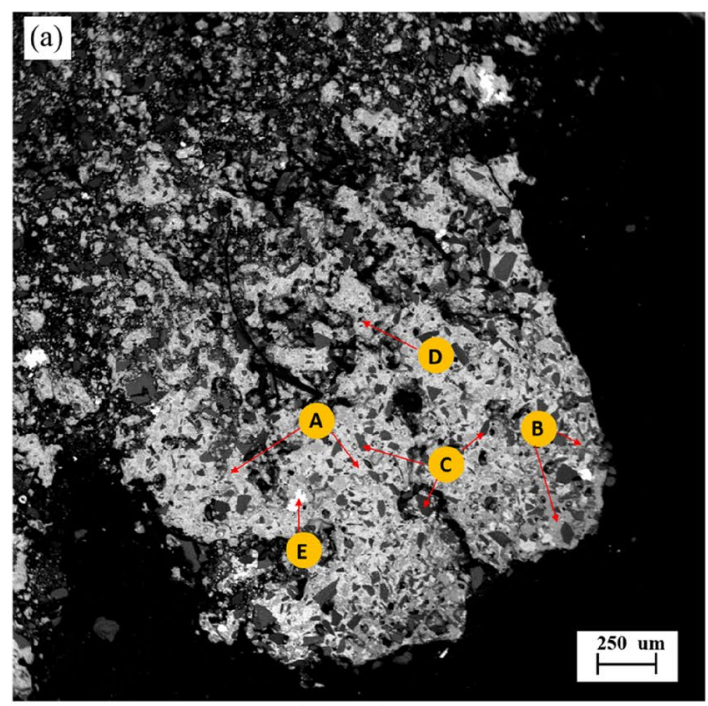

(a) $t=10 \mathrm{~s}$

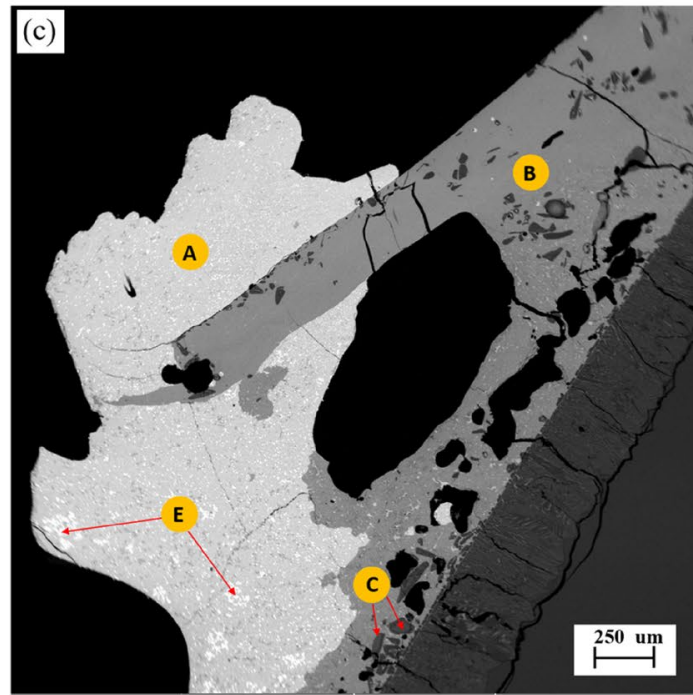

(c) $t=30 \mathrm{~s}$

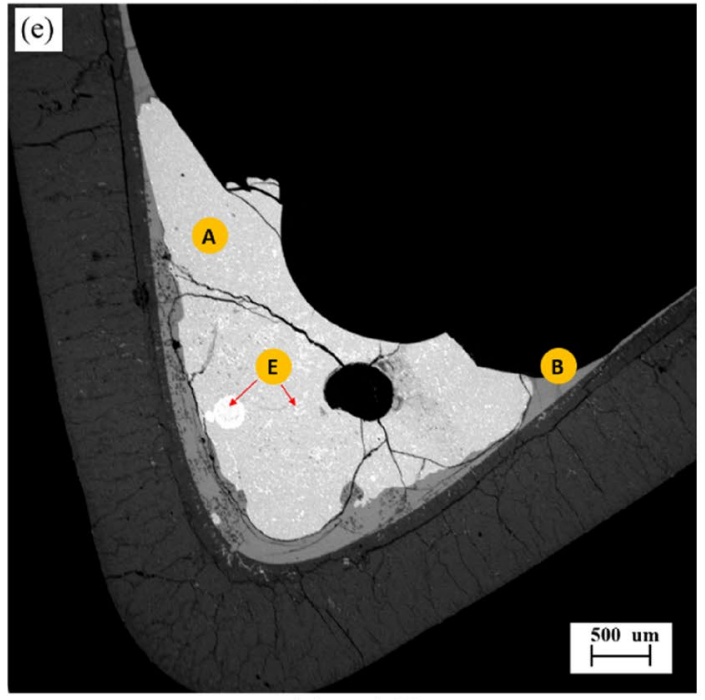

(e) $t=150 \mathrm{~s}$

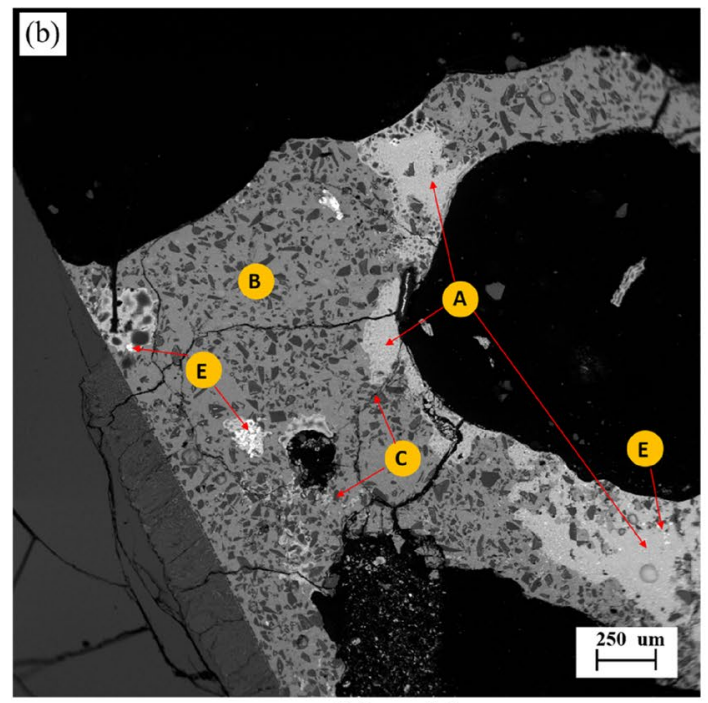

(b) $\mathrm{t}=20 \mathrm{~s}$

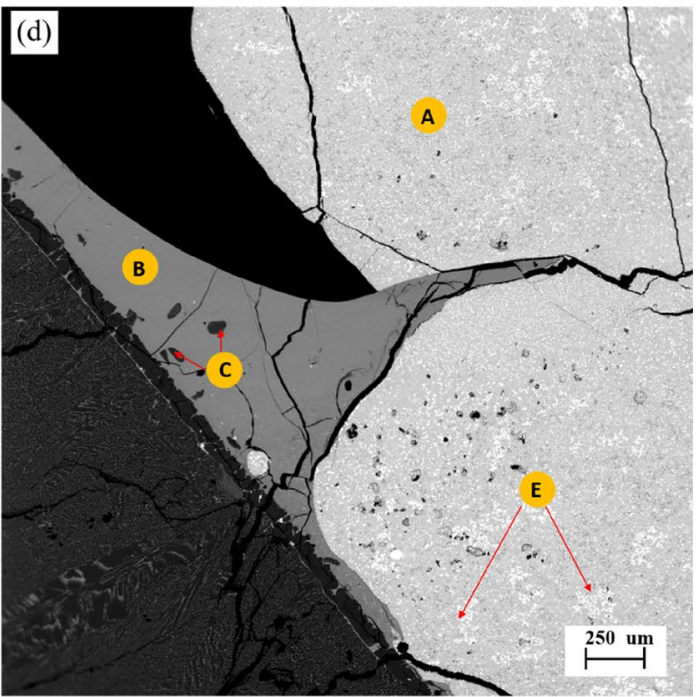

(d) $t=60 \mathrm{~s}$

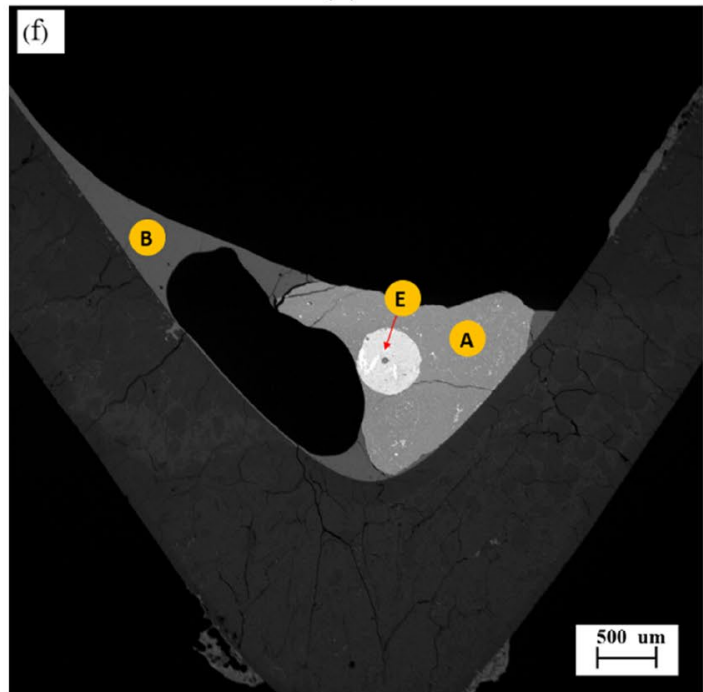

(f) $t=300 \mathrm{~s}$

Fig. 2 Micrographs of samples treated in air after different reaction times. a Matte, $\mathbf{b}$ fayalite slag, $\mathbf{c}$ silica, $\mathbf{d}$ ferric oxide, and e PMs-Cu-Fe droplet clusters 


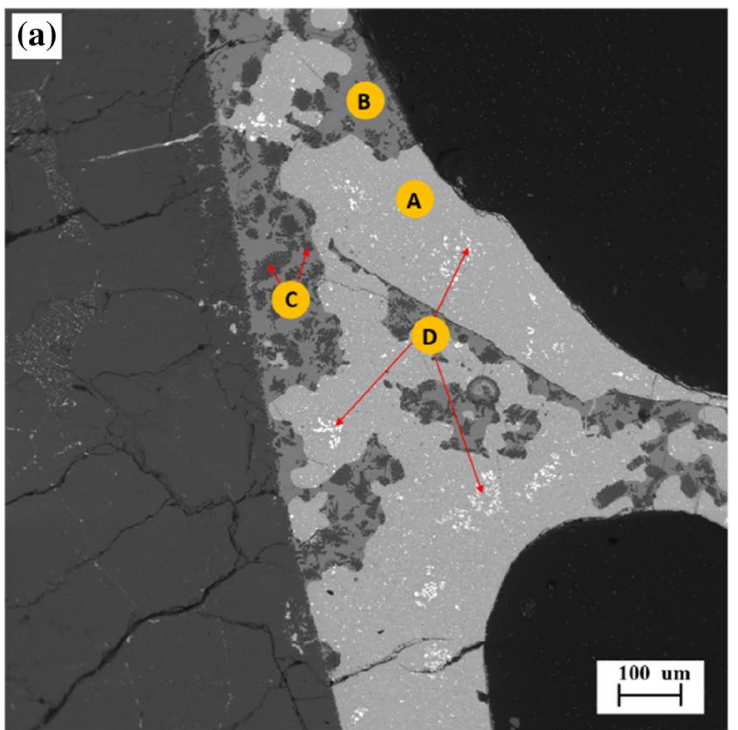

(a) $t=5$ min

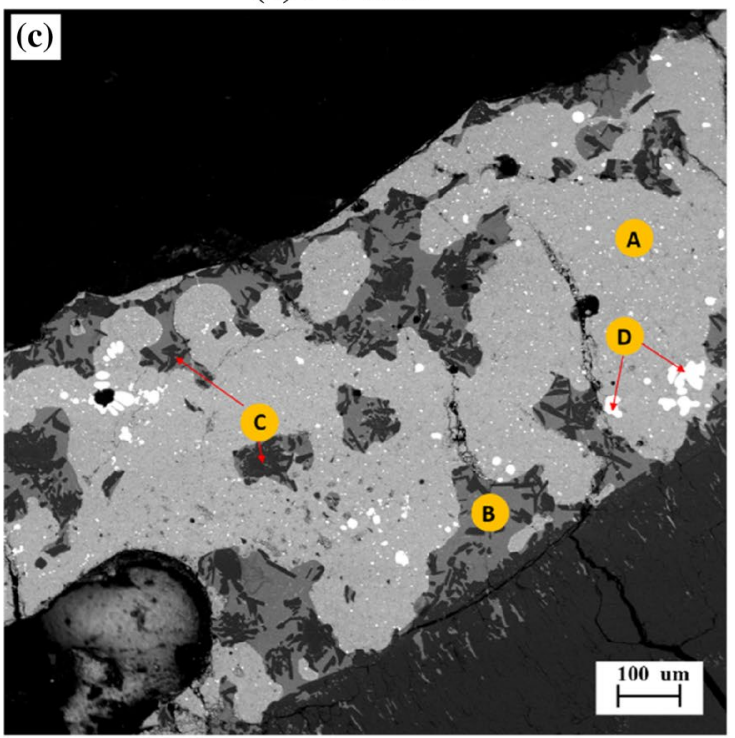

(c) $\mathrm{t}=20 \mathrm{~min}$

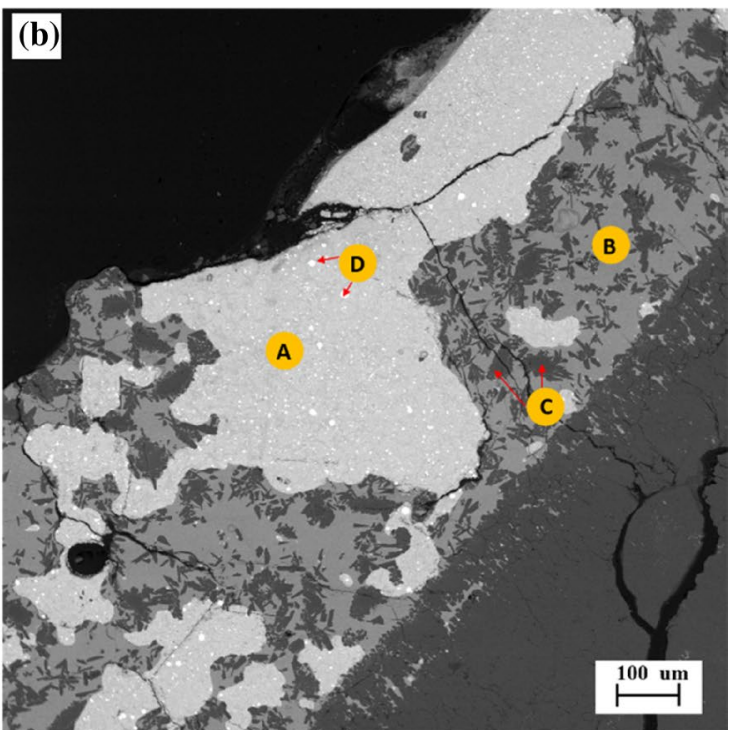

(b) $\mathrm{t}=10 \mathrm{~min}$

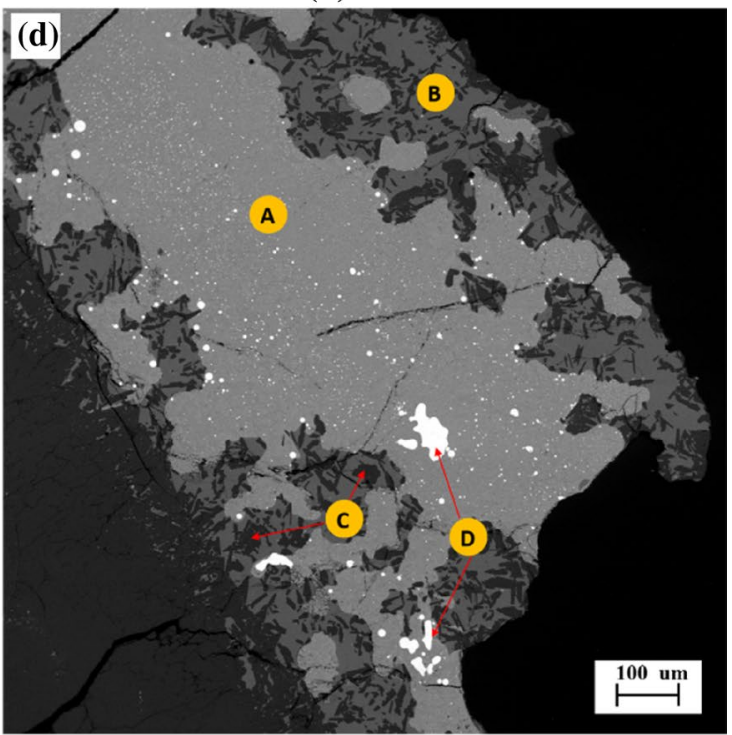

(d) $\mathrm{t}=40 \mathrm{~min}$

Fig. 3 Micrographs of samples treated in argon after different reaction times. a Matte, $\mathbf{b}$ fayalite slag, $\mathbf{c}$ silica, and $\mathbf{d}$ PMs-Cu-Fe droplet clusters

(Fig. 6a), the $\mathrm{Au}, \mathrm{Ag}$, and Pd concentrations in matte consistently increased with longer contact times. The platinum concentration began to decrease after $150 \mathrm{~s}$, which can be explained by the formation of large platinum-rich droplets in the matte, shown in Fig. 3e-f. In the argon atmosphere (Fig. 6b), the PM concentrations remained relatively constant as a function of time. After the longest contact times, all the PM concentrations in matte were lower in argon than in air. The sequence of concentration levels in both atmospheres was $\mathrm{Ag}>\mathrm{Pd}>\mathrm{Au}>\mathrm{Pt}$.

The concentrations of the PMs $\mathrm{Au}, \mathrm{Ag}, \mathrm{Pt}$, and $\mathrm{Pd}$ in slag as a function of time are shown in Fig. 7. The slag chemistry plays an important role in the elimination of impurity elements and recovery of precious metals in copper smelting. In the $\mathrm{FeO}_{X}-\mathrm{SiO}_{2}$ slag used in this study, all precious metal concentrations initially decreased as a function of time and then stabilized at a constant level. The sequence of PM concentrations in the slag was $\mathrm{Ag}>\mathrm{Au}>\mathrm{Pd}>\mathrm{Pt}$ in both air (Fig. 7a) and argon (Fig. 7b) atmospheres. However, the PM concentrations were higher in air than in the argon atmosphere after reaching stable concentration levels.

The distribution reaction for precious metal Me between matte and slag can be described using Eq. (1), when metals are deported into the slag phase due to the oxidation reaction: 

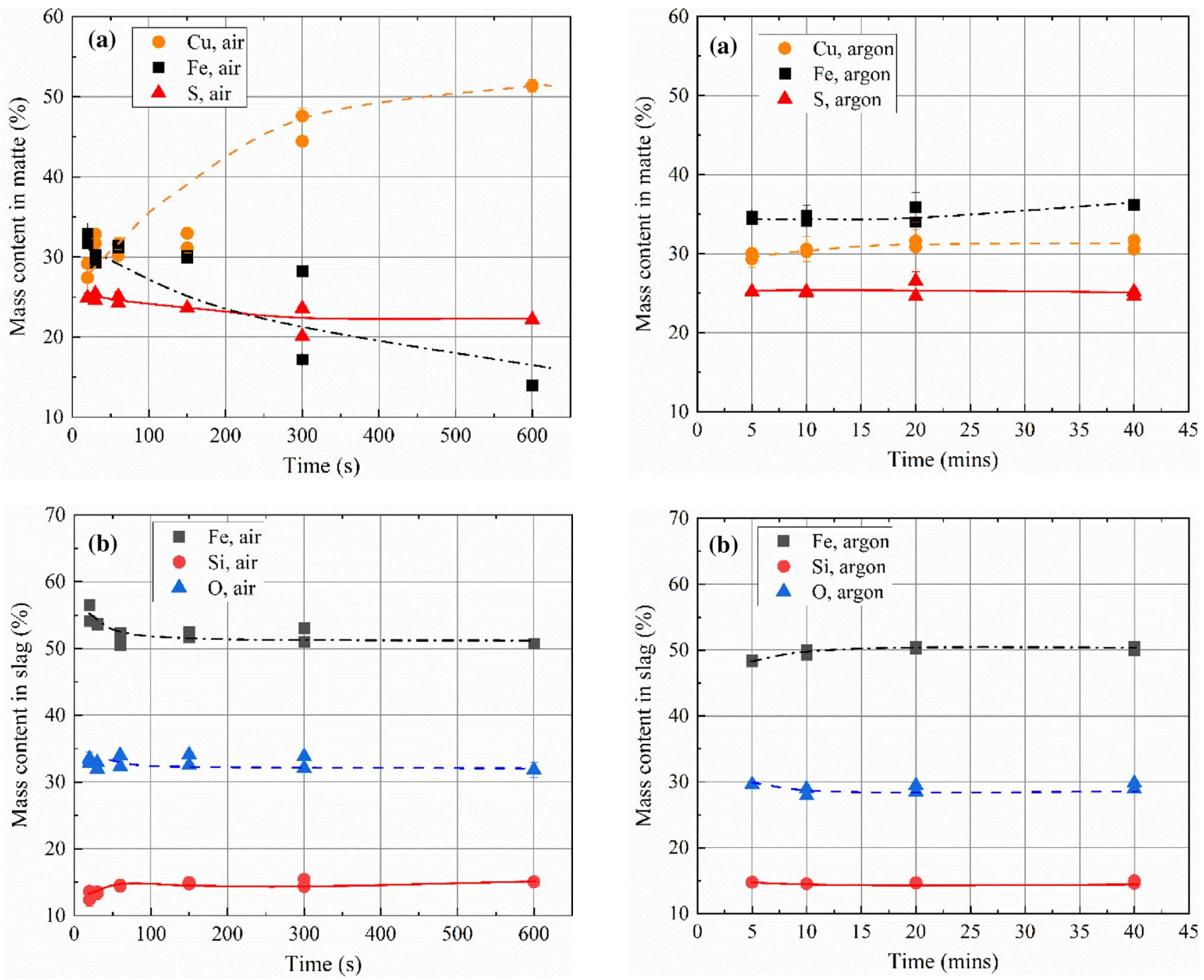

Fig. 4 Chemical assays of matte (a) and slag (b) as a function of time in air-atmosphere experiments

$\mathrm{Me}+x / 2 \mathrm{O}_{2}(g)=\mathrm{MO}_{x}$.

Equation (1) can be presented using an equilibrium constant that consists of the activities of the species and the prevailing oxygen partial pressure, shown in Eq. (2). The activities can be expressed with the concentration of the species and its activity coefficient, as in Eqs. (3) and (4).

$$
\begin{aligned}
& K=\frac{\alpha \mathrm{MeO}_{x}}{\alpha \mathrm{Me} \cdot \mathrm{PO}_{2}^{x / 2}}, \\
& a_{\mathrm{Me}}=\gamma_{\mathrm{Me}} \mathrm{N}_{\mathrm{Me}}=\gamma_{\mathrm{Me}}[\mathrm{Me} \mathrm{wt} \%] / \mathrm{M}_{\mathrm{Me}}\left[n_{\mathrm{T}}\right], \\
& a_{\mathrm{MeO} x}=\gamma_{\mathrm{MeO} x} \mathrm{~N}_{\mathrm{MeO} x}=\gamma_{\mathrm{MeO} x}(\mathrm{wt} \% \mathrm{Me}) / \mathrm{M}_{\mathrm{Me}}\left(n_{\mathrm{T}}\right),
\end{aligned}
$$

Fig. 5 Chemical assays of matte (a) and slag (b) as a function of time in argon-atmosphere experiments

where $K$ is the equilibrium constant, and $\alpha \mathrm{Me}$ and $\alpha \mathrm{MeO}_{x}$ represent the activities of metal $\mathrm{Me}$ and metal oxide $\mathrm{MeO}_{x}$, respectively. $\gamma \mathrm{Me}$ is the activity coefficient of $\mathrm{Me}$ and $\gamma \mathrm{MeO}$ is the activity coefficient of $\mathrm{MeO}_{x}$. $\mathrm{N}_{\mathrm{Me}}$ is the molar fraction of metal Me, $n_{\mathrm{T}}$ is the total number of moles of monocationic constituents in $100 \mathrm{~g}$ of each phase, $\mathrm{M}_{\mathrm{me}}$ is the atomic mass of $\mathrm{Me}$, and wt\% $\mathrm{Me}$ is the weight percentage in matte and slag.

In the equilibrium studies, the distribution coefficient of a PM Me between copper matte and slag is defined by Eq. (5), where [Me wt\%] refers to the equilibrium concentration of $\mathrm{Me}$ in copper matte and (Me wt \%) is the equilibrium concentration in slag in weight percentage [30].

$L^{\mathrm{m} / \mathrm{s}}(\mathrm{Me})=[\mathrm{Me} \mathrm{wt} \%] /(\mathrm{Me} \mathrm{wt} \%)$. 

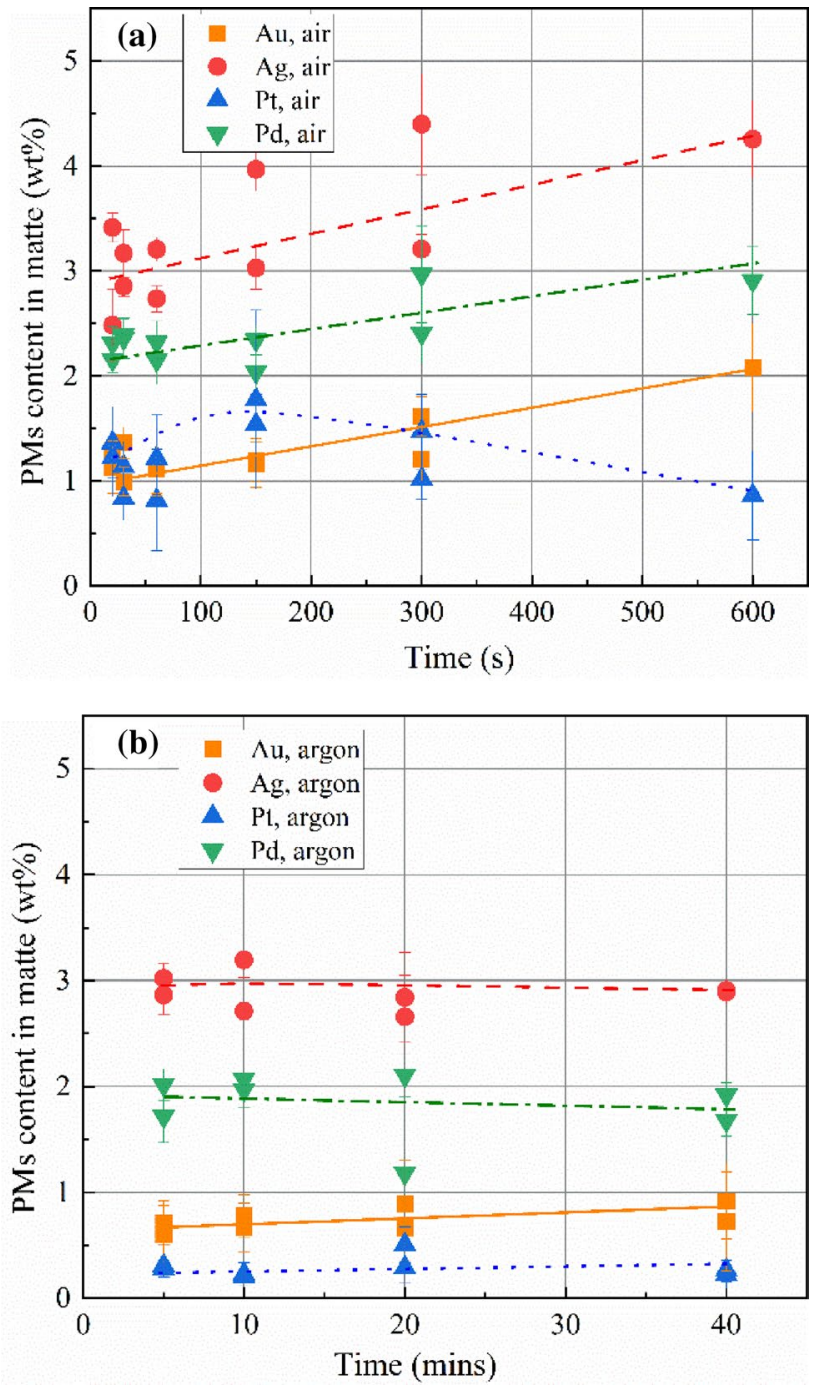

Fig. 6 Concentrations of PMs in matte phase as a function of time: a air atmosphere, $\mathbf{b}$ argon atmosphere

Combining Eqs. (1)-(4), Eq. (5) can be expressed as follows:

$L^{\mathrm{m} / \mathrm{s}}(\mathrm{Me})=\frac{[\mathrm{Me} \mathrm{wt} \%]}{(\mathrm{Mewt} \%)}=\frac{\left[n_{\mathrm{T}}\right]\left(\gamma \mathrm{MeO}_{x}\right)}{K \cdot\left(n_{\mathrm{T}}\right)[\gamma \mathrm{Me}] \mathrm{P}_{\mathrm{O}_{2}}^{x / 2}}$.

As shown by Eq. (6), the distribution coefficient is a practical and independent thermodynamic parameter of the matte-slag system (only influenced by the temperature, oxygen potential, etc.), so the concentrations of the initial precious metals will not influence the distribution results. Even though these noble metal concentrations in this study are higher than those in real WPCBs, the distribution ratios between the matte and slag should be thermodynamically independent. In that case, the distribution coefficients between matte and slag are essential parameters
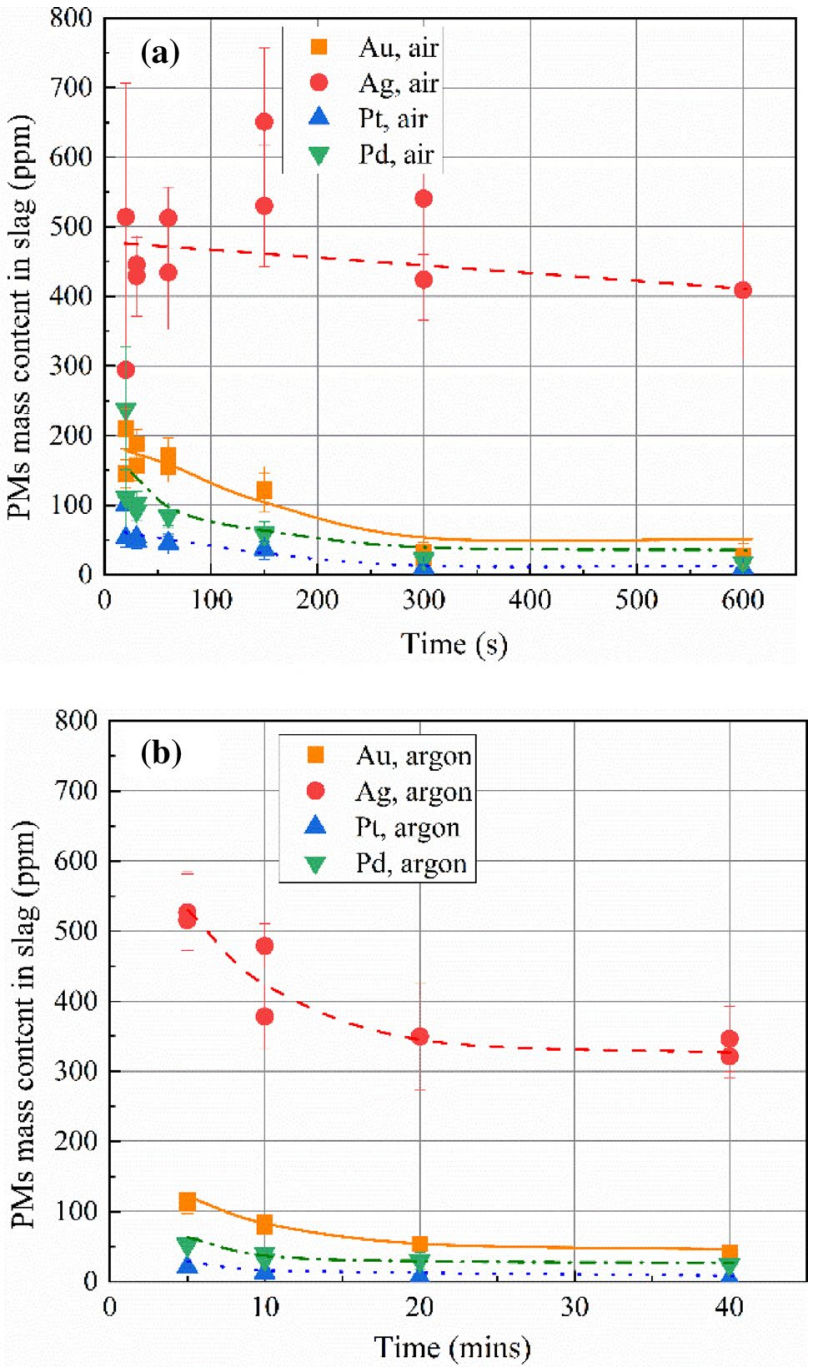

Fig. 7 Concentrations of $\mathrm{PMs}$ in $\mathrm{FeO}_{\mathrm{x}}-\mathrm{SiO}_{2}$ slag as a function of time: a air atmosphere, $\mathbf{b}$ argon atmosphere

for evaluating the recycling efficiencies of the PMs during copper smelting, by utilizing copper matte as a medium for their collection. In this kinetic study, the distribution coefficients values of PMs were determined at selected times by Eq. (7), where $t$ refers to the contact time after which the sample was quenched and the reactions stopped [45].

$L^{\mathrm{m} / \mathrm{s}}(\mathrm{Me})_{t}=\left([\mathrm{Me} \mathrm{wt} \%]_{t} /(\mathrm{Me} \mathrm{wt} \%)_{t}\right)$.

The logarithmic values of distribution coefficients $L^{\mathrm{m} / \mathrm{s}}$ (Me) between matte and slag during the oxidation reactions in air are shown in Fig. 8. All PMs were found to deport strongly into the matte rather than into the slag, and with the increased contact time, their distribution coefficients followed a similar increasing tendency until $300 \mathrm{~s}$, after which the values stabilized in the order of $\mathrm{Pd}>\mathrm{Pt}>\mathrm{Au}>\mathrm{Ag}$. At $20 \mathrm{~s}$ contact time, the average 


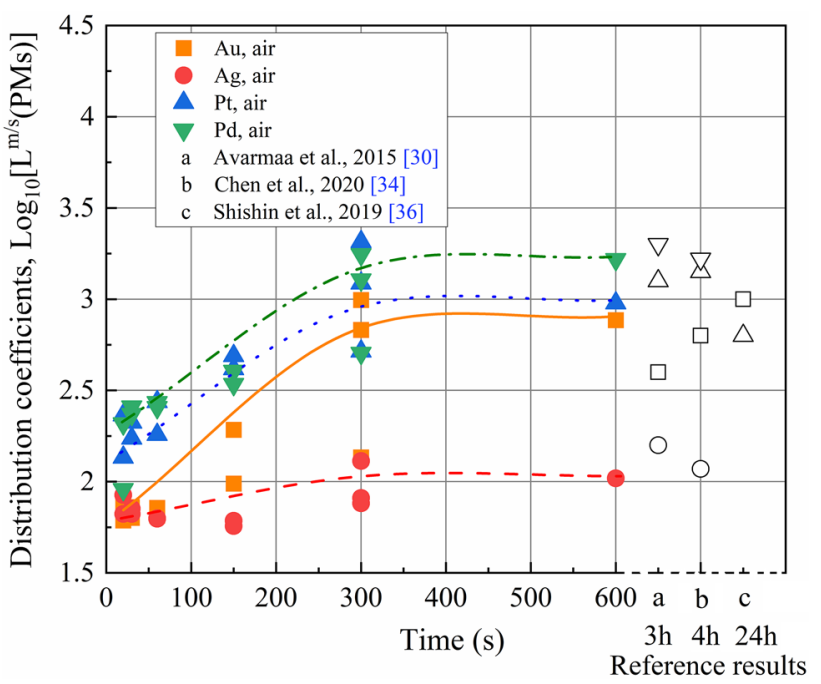

Fig. 8 Logarithmic distribution coefficients of gold, silver, platinum, and palladium between matte and $\mathrm{FeO}_{x}-\mathrm{SiO}_{2}$ slag as a function of time in air atmosphere

distribution coefficient values for $\mathrm{Au}, \mathrm{Ag}, \mathrm{Pt}$, and $\mathrm{Pd}$ were $80,70,230$, and 200, respectively, and at $300 \mathrm{~s}$, these values surged to $600,100,1300$, and 1200. During this time period, the matte grade also gradually increased. This also helped improve PM migration into the matte phase [36]. Tags $a, b, c$ on the $x$-axis of Fig. 8 refer to the PM distribution results from equilibration studies between matte and iron-silicate slag where the temperature and matte grade were closest to the parameters in this work (a-Avarmaa et al. [30]; b-Chen et al. [34]; c-Shishin et al. [36]). The equilibration time in their studies was $3 \mathrm{~h}, 4 \mathrm{~h}$, and $24 \mathrm{~h}$, respectively. After 300-600 s, the distribution coefficients of the PMs obtained in this work agreed well with these recent equilibrium studies. Therefore, it seems that the equilibrium distribution coefficient values for PMs can be reached even in relatively short contact times.

The distribution coefficients of PMs in argon are shown in Fig. 9. The values are lower than those in air, but they still follow the same order of $\mathrm{Pd}>\mathrm{Pt}>\mathrm{Au}>\mathrm{Ag}$. As shown in Fig. 5a, the matte grade ( $\mathrm{wt} \% \mathrm{Cu}$ ) was relatively constant in the argon atmosphere; however, the distribution coefficients continued to increase as a function of time. This means that sufficient time is needed for the PMs to migrate to the matte phase in low oxygen partial pressures. In air, the obtained distribution coefficients stabilized after $300 \mathrm{~s}$, while the values in argon continued to increase slightly until the longest investigated contact time of $40 \mathrm{~min}$. The average distribution coefficients values after $40 \mathrm{~min}$ for $\mathrm{Au}, \mathrm{Ag}, \mathrm{Pt}$, and $\mathrm{Pd}$ were approximately 200, 90, 710, and 750, respectively, i.e., somewhat lower than the corresponding results in air.

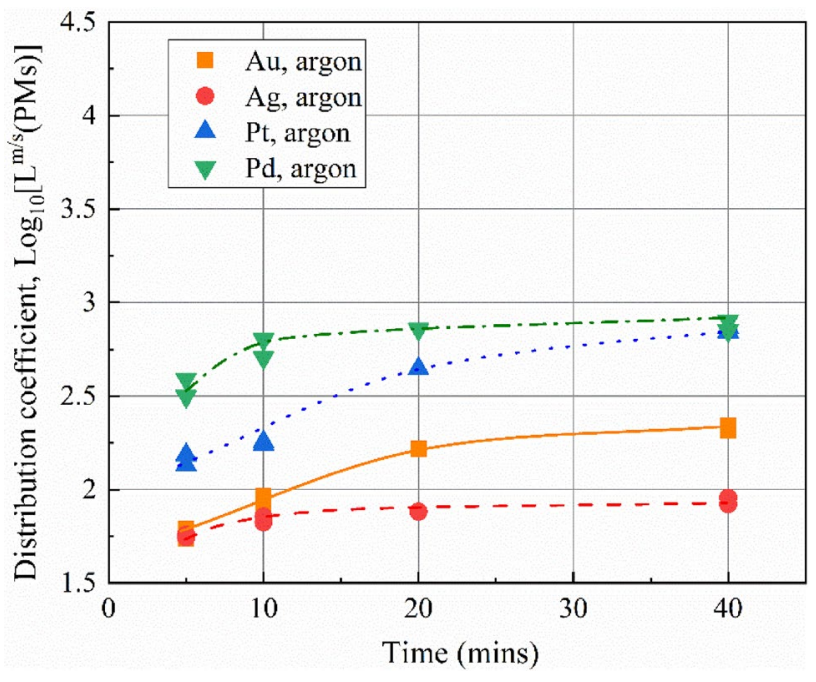

Fig. 9 Logarithmic distribution coefficients of gold, silver, platinum, and palladium between matte and $\mathrm{FeO}_{x}-\mathrm{SiO}_{2}$ slag as a function of time in argon atmosphere

\section{Conclusions}

No previous data exist on the kinetic behavior of precious metals (PMs) in copper flash smelting conditions. In this study, the behavior of $\mathrm{Au}, \mathrm{Ag}, \mathrm{Pt}$, and $\mathrm{Pd}$ was investigated in laboratory-scale experiments at a typical smelting temperature of $1300{ }^{\circ} \mathrm{C}$ in both air and argon atmospheres. The samples were analyzed by SEM-EDS for visual and preliminary compositional information, and by EPMA (matte) and LAICP-MS (slag) for more accurate phase composition data.

All the PMs studied in this work strongly preferred to deport into the matte rather than the slag phase. The novelty of the present research is the experimental proof that the studied PMs migrate to the matte phase almost instantly when the molten matte and slag begin to form. The PMs approached their reported equilibrium distribution coefficients after only $300 \mathrm{~s}$ contact time in the air atmosphere. However, it should be noted that the experimental conditions, mainly the gas atmospheres, in the earlier equilibrium studies did not fully correspond to those utilized in this work, and industrial copper concentrate was used in this study. In the argon atmosphere, the distribution coefficient values slightly increased during the entire contact time of $40 \mathrm{~min}$. The calculated distribution coefficients $L^{\mathrm{m} / \mathrm{s}}(\mathrm{Me})$, based on experimentally measured element concentrations, followed the order of $\mathrm{Pd}>\mathrm{Pt}>\mathrm{Au}>\mathrm{Ag}$ in both air and argon atmospheres.

The distribution coefficients of PMs in air were higher than the results in argon, and PM concentrations in matte increased with longer contact time and higher matte grade. The oxygen potential had an impact on the PM migration rates and distribution coefficients. Based on the results in 
argon, considerably longer times are needed for the complete transfer of PMs to the matte at low oxygen potentials.

After reaching stable levels, the PM concentrations in the slag were relatively low, at approximately $408 \mathrm{ppm}$ $(\mathrm{Ag}), 27 \mathrm{ppm}(\mathrm{Au}), 17 \mathrm{ppm}(\mathrm{Pd})$, and $9 \mathrm{ppm}(\mathrm{Pt})$ in air, and $346 \mathrm{ppm}(\mathrm{Ag}), 42 \mathrm{ppm}(\mathrm{Au}), 24 \mathrm{ppm}(\mathrm{Pd})$, and 3 ppm (Pt) in argon. These low concentrations of chemically dissolved PMs in the slag indicated that copper matte can perform as an excellent collector to recover precious metals. This suggests that the highest PM losses in industrial operations most likely arise from mechanical matte entrainment.

These new experimental results regarding the effect of time on PM distribution behavior can be used for updating databases related to secondary raw materials processing via copper smelting and also for CFD models to simulate the behavior of precious metals in smelting processes more precisely.

Acknowledgements This work was financially supported by the Aalto University School of Chemical Engineering and the Business Finland financed SYMMET project [Grant number 3891/31/2018]. Thanks to Outotec Research Center (Pori, Finland) for their contribution. This study utilized the Academy of Finland's RawMatTERS Finland Infrastructure (RAMI) based jointly at Aalto University, GTK, and VTT in Espoo. Xingbang Wan would also like to acknowledge the financial support from the China Scholarship Council [Grant Number 201706370096]

Funding Open access funding provided by Aalto University.

\section{Declaration}

Conflict of interest The authors report no conflicts of interest and the authors alone are responsible for the content and writing of the article.

Open Access This article is licensed under a Creative Commons Attribution 4.0 International License, which permits use, sharing, adaptation, distribution and reproduction in any medium or format, as long as you give appropriate credit to the original author(s) and the source, provide a link to the Creative Commons licence, and indicate if changes were made. The images or other third party material in this article are included in the article's Creative Commons licence, unless indicated otherwise in a credit line to the material. If material is not included in the article's Creative Commons licence and your intended use is not permitted by statutory regulation or exceeds the permitted use, you will need to obtain permission directly from the copyright holder. To view a copy of this licence, visit http://creativecommons.org/licenses/by/4.0/.

\section{References}

1. Cayumil R, Khanna R, Rajarao R, Mukherjee P, Sahajwalla V (2016) Concentration of precious metals during their recovery from electronic waste. Waste Manag 57:121-130. https://doi.org/ 10.1016/j.wasman.2015.12.004

2. Baldé C, Forti V, Gray V, Kuehr R, Stegmann P (2017) The global E-waste monitor-2017, United Nations University (UNU), International Telecommunication Union (ITU) \& International Solid
Waste Association (ISWA), Bonn/Geneva/Vienna. Electronic Version. 978-992

3. Vegliò F, Birloaga I (eds) (2018) Waste electrical and electronic equipment recycling: aqueous recovery methods. 1st edition. Woodhead Publishing, United Kingdom. eBook ISBN: 9780081020586

4. Ilankoon I, Ghorbani Y, Chong MN, Herath G, Moyo T, Petersen $\mathrm{J}$ (2018) E-waste in the international context-A review of trade flows, regulations, hazards, waste management strategies and technologies for value recovery. Waste Manag 82:258-275. https://doi. org/10.1016/j.wasman.2018.10.018

5. Chagnes A, Cote G, Ekberg C, Nilsson M, Retegan T (2016) WEEE recycling: research, development, and policies. 1st edition. Elsevier. eBook ISBN: 9780128033647

6. Wan X, Taskinen P, Shi J, Jokilaakso A (2021) A potential industrial waste-waste co-treatment process of utilizing waste $\mathrm{SO} 2$ gas and residue heat to recover $\mathrm{Co}, \mathrm{Ni}$, and $\mathrm{Cu}$ from copper smelting slag. J Hazard Mater 414:125541. https://doi.org/10. 1016/j.jhazmat.2021.125541

7. Anindya A (2012) Minor elements distribution during the smelting of WEEE with copper scrap. Doctoral thesis, RMIT university, Melbourne, Australia

8. Anindya A, Swinbourne D, Reuter M, Matusewicz R (2013) Distribution of elements between copper and $\mathrm{FeO}_{\mathrm{x}}-\mathrm{CaO}-\mathrm{SiO}_{2}$ slags during pyrometallurgical processing of WEEE: Part 1Tin. Miner Process Extr Metall 122(3):165-173. https://doi.org/ 10.1179/1743285513Y.0000000043

9. Kaya M (2016) Recovery of metals and nonmetals from electronic waste by physical and chemical recycling processes. Waste Manag 57:64-90. https://doi.org/10.1016/j.wasman.2016. 08.004

10. Hughes S, Jåfs M, Johto H, Stål J, Karonen J (2019) Outotec solutions for E-scrap processing, REWAS 2019. Springer, Berlin, pp 283-294. https://doi.org/10.1007/978-3-030-10386-6

11. Puca A, Carrano M, Liu G, Musella D, Ripa M, Viglia S, Ulgiati S (2017) Energy and exergy assessment of the production and operation of a personal computer. Resour Conserv Recycl 116:124-136. https://doi.org/10.1016/j.resconrec.2016.09.030

12. Chancerel P, Meskers CE, Hagelüken C, Rotter VS (2009) Assessment of precious metal flows during preprocessing of waste electrical and electronic equipment. J Ind Ecol 13(5):791-810. https:// doi.org/10.1111/j.1530-9290.2009.00171.x

13. Cui J, Zhang L (2008) Metallurgical recovery of metals from electronic waste: a review. J Hazard Mater 158(2-3):228-256. https:// doi.org/10.1016/j.jhazmat.2008.02.001

14. Ebin B, Isik MI (2016) Pyrometallurgical processes for the recovery of metals from WEEE. In: WEEE recycling. Elsevier, pp. 107-137. https://doi.org/10.1016/B978-0-12-803363-0.00005-5

15. Wang H, Zhang S, Li B, Pan DA, Wu Y, Zuo T (2017) Recovery of waste printed circuit boards through pyrometallurgical processing: a review. Resour Conserv Recycl 126:209-218. https://doi. org/10.1016/j.resconrec.2017.08.001

16. He W, Li G, Ma X, Wang H, Huang J, Xu M, Huang C (2006) WEEE recovery strategies and the WEEE treatment status in China. J Hazard Mater 136(3):502-512

17. Sum EY (1991) The recovery of metals from electronic scrap. JOM 43(4):53-61. https://doi.org/10.1007/BF03220549

18. Khaliq A, Rhamdhani MA, Brooks G, Masood S (2014) Metal extraction processes for electronic waste and existing industrial routes: a review and Australian perspective. Resource 3(1):152179. https://doi.org/10.3390/resources3010152

19. Kojo IV, Jokilaakso A, Hanniala P (2000) Flash smelting and converting furnaces: a 50 year retrospect. JOM 52(2):57-61. https:// doi.org/10.1007/s11837-000-0049-5

20. Taskinen P, Seppälä K, Laulumaa J, Poijärvi J (2001) Oxygen pressure in the Outokumpu flash smelting furnace-Part 1: copper 
flash smelting settler. Miner Process Extr Metall 110(2):94-100. https://doi.org/10.1179/mpm.2001.110.2.94

21. Taskinen P, Seppälä K, Laulumaa J, Poijärvi J (2001) Oxygen pressure in the Outokumpu flash smelting furnace-Part 2: the DON process. Miner Process Extr Metall 110(2):101-108. https:// doi.org/10.1179/mpm.2001.110.2.101

22. Jorgensen FR (1983) Single-particle combustion of chalcopyrite. Proc Austral Inst Min Metall 288:37-46

23. Jokilaakso A, Suominen R, Taskinen P, Lilius K (1991) Oxidation of chalcopyrite in simulated suspension smelting. Trans Inst Min Metall (Sect C: Miner Process Extr Metall) 100:C79-C90

24. Wan X, Shen L, Jokilaakso A, Eriç H, Taskinen P (2020) Experimental approach to matte-slag reactions in the Flash Smelting Process. Miner Process Extr Metall Rev 42:231-241. https://doi. org/10.1080/08827508.2020.1737801

25. Guntoro PI, Jokilaakso A, Hellstén N, Taskinen P (2018) Copper matte-slag reaction sequences and separation processes in matte smelting. J Min Metall Sect B 54(3):301-311. https://doi.org/10. 2298/jmmb180214021g

26. Ma E (2019) Recovery of waste printed circuit boards through pyrometallurgy. Electron Waste Manag Technol Treat Technol. https://doi.org/10.1016/B978-0-12-816190-6.00011-X

27. Sukhomlinov D, Avarmaa K, Virtanen O, Taskinen P, Jokilaakso A (2019) Slag-copper equilibria of selected trace elements in black copper smelting. Part I. Properties of the slag and chromium solubility. Miner Process Extr Metall Rev. https://doi.org/10.1080/ 08827508.2019.1575212

28. Sukhomlinov D, Avarmaa K, Virtanen O, Taskinen P, Jokilaakso A (2020) Slag-copper equilibria of selected trace elements in black-copper smelting. Part II. Trace element distributions. Miner Process Extr Metall Rev 41(3):171-177. https://doi.org/10.1080/ 08827508.2019.1634561

29. Roghani G, Font JC, Hino M, Itagaki K (1996) Distribution of minor elements between calcium ferrite slag and copper matte at $1523 \mathrm{~K}$ under high partial pressure of $\mathrm{SO}_{2}$. Mater Trans, JIM 37(10):1574-1579. https://doi.org/10.2320/matertrans1989.37. 1574

30. Avarmaa K, O'Brien H, Johto H, Taskinen P (2015) Equilibrium distribution of precious metals between slag and copper matte at 1250-1350 \& \#xB0;C. J Sustain Metall 1(3):216-228. https://doi. org/10.1007/s11663-015-0498-4

31. Avarmaa K, Johto H, Taskinen P (2016) Distribution of precious metals ( $\mathrm{Ag}, \mathrm{Au}, \mathrm{Pd}, \mathrm{Pt}$, and $\mathrm{Rh}$ ) between copper matte and iron silicate slag. Metall Mater Trans B 47(1):244-255. https://doi.org/ 10.1007/s11663-015-0498-4

32. Roghani G, Takeda Y, Itagaki K (2000) Phase equilibrium and minor element distribution between $\mathrm{FeO}_{\mathrm{x}}-\mathrm{SiO}_{2}-\mathrm{MgO}$-based slag and $\mathrm{Cu}_{2} \mathrm{~S}-\mathrm{FeS}$ matte at $1573 \mathrm{~K}$ under high partial pressures of $\mathrm{SO}_{2}$. Min Metall Sect B. 31(4):705-712

33. Roghani G, Hino M, Itagaki K (1997) Phase equilibrium and minor elements distribution between $\mathrm{SiO}_{2}-\mathrm{CaO}-\mathrm{FeO}_{\mathrm{x}}-\mathrm{MgO}$ slag and copper matte at $1573 \mathrm{~K}$ under high partial pressures of $\mathrm{SO}_{2}$. Mater Trans, JIM 38(8):707-713. https://doi.org/10.2320/mater trans1989.38.707

34. Chen M, Avarmaa K, Klemettinen L, O'Brien H, Sukhomlinov D, Shi J, Taskinen P, Jokilaakso A (2020) Recovery of precious metals (Au, Ag, Pt, and Pd) from urban mining through copper smelting. Metall Mater Trans B 51:1495-1508. https://doi.org/10. 1007/s11663-020-01861-5
35. Chen M, Avarmaa K, Klemettinen L, Shi J, Taskinen P, Jokilaakso A (2020) Experimental study on the phase equilibrium of copper matte and silica-saturated $\mathrm{FeO}_{\mathrm{x}}-\mathrm{SiO}_{2}$-based slags in pyrometallurgical. WEEE Process Metall Mater Trans B 51:1552-1563. https://doi.org/10.1007/s11663-020-01874-0

36. Shishin D, Hidayat T, Chen J, Hayes PC, Jak E (2019) Experimental investigation and thermodynamic modeling of the distributions of $\mathrm{Ag}$ and $\mathrm{Au}$ between slag, matte, and metal in the $\mathrm{Cu}-\mathrm{Fe}-\mathrm{O}-\mathrm{S}-$ Si system. J Sustain Metall 5(2):240-249. https://doi.org/10.1007/ s40831-019-00218-w

37. Wan X, Fellman J, Jokilaakso A, Klemettinen L, Marjakoski M (2018) Behavior of waste printed circuit board (WPCB) materials in the copper matte smelting process. Metals 8(11):887. https:// doi.org/10.3390/met8110887

38. Wan X, Jokilaakso A, Iduozee I, Eric H, Latostenmaa P (2019) Experimental research on the behavior of WEEE scrap in flash smelting settler with copper concentrate and synthetic slag. In: Proceedings of the EMC 2019, Düsseldorf, Germany, 23-26 June 2019, vol 3, pp 1137-1150. IASN 978-3-940276-89-6

39. Wu Z, Yuan W, Li J, Wang X, Liu L, Wang J (2017) A critical review on the recycling of copper and precious metals from waste printed circuit boards using hydrometallurgy. Front Environ Sci Eng 11(5):8. https://doi.org/10.1007/s11783-017-0995-6

40. Klemettinen L, Aromaa R, Dańczak A, O’Brien H, Taskinen P, Jokilaakso A (2020) Distribution kinetics of rare earth elements in copper smelting. Sustainability 12(1):208. https://doi.org/10. 3390/su12010208

41. Wan X, Chen M, Qiu Y, Shi J, Li J, Liu C, Taskinen P, Jokilaakso A (2020) Influence of manganese oxide on the liquid-perovskite equilibrium in the $\mathrm{CaO}-\mathrm{SiO}_{2}-\mathrm{TiO}_{2}$ system at $1400^{\circ} \mathrm{C}$ in air. Ceram Int. https://doi.org/10.1016/j.ceramint.2020.12.241

42. Klemettinen L, Taskinen P, O'Brien H, Jokilaakso A (2019) Equilibrium studies: experimental techniques and characterization methods at Aalto University, Finland. In Proceedings of international multidisciplinary geosciences conference-IMGC2019, University of Mitrovica, Republic of Kosovo, pp 93-103

43. Avarmaa K (2019) Thermodynamic properties of WEEE-based minor elements in copper smelting processes. PhD diss., Aalto University, Finland

44. Chen M, Avarmaa K, Klemettinen L, O'Brien H, Shi J, Taskinen P, Lindberg D, Jokilaakso A (2021) Precious metal distributions between copper matte and slag at high $\mathrm{P}_{\mathrm{SO} 2}$ in WEEE reprocessing. Metall Mater Trans B 52:871-882. https://doi.org/10.1007/ s11663-021-02059-z

45. Wan X, Taskinen P, Shi J, Klemettinen L, Jokilaakso A (2021) Reaction mechanisms of waste printed circuit board recycling in copper smelting: the impurity elements. Miner Eng 160:106709. https://doi.org/10.1016/j.mineng.2020.106709

46. Asaki Z (1992) Kinetic studies of copper flash smelting furnace and improvements of its operation in the smelters in Japan. Miner Process Extr Metall Rev 11(3):163-185. https://doi.org/10.1080/ 08827509208914210

Publisher's Note Springer Nature remains neutral with regard to jurisdictional claims in published maps and institutional affiliations. 